\title{
Investigating How Voters Weigh Issues and Partisanship in Judicial Elections
}

\author{
Mark J. McKenzie, Cynthia R. Rugeley, and Michael A. Unger
}

Drawing on a 2009 statewide telephone poll of registered voters in Texas, this study investigates how voters react to politicized campaigning, judicial experience and partisan cues when voting for judge. We analyze individual-level data by employing an experimental design in which respondents were provided information about a hypothetical judicial candidate (varying in both campaign theme and in partisanship) and then asked about the likelihood of voting for that candidate. We found that in a partisan election state such as Texas, individuals rely heavily on party as a shortcut when evaluating judicial candidates, even when accounting for judicial experience. We also found that respondents with greater levels of political sophistication were more likely to be influenced by a candidate's issue position on frivolous lawsuits.

As judicial elections become costlier and more politicized, how will voters respond to candidates who emphasize legal experience and qualifications versus issues and to what extent do partisan cues overwhelm such calls? Although individual level studies of voting behavior in judicial elections are not common, political scientists have established a number of principles. First, most studies suggest that voters in judicial elections behave no differently than they do in voting in other races, using partisanship and party cues when they are available to assist them in their decision (e.g., Baum 1987b). Second, aggregate level studies indicate that experience matters to voters in judicial elections (e.g., Bonneau and Hall 2009; Dubois 1984; Hall and Bonneau 2006). And third, there is some individual-level data showing evidence of issue-based voting in judicial elections, though studies in this area are very sparse (but see Baum and Klein 2007; Hojnacki and Baum 1992). Anecdotal evidence also suggests a fair amount of issue voting can occur. ${ }^{1}$ What's missing in the current line of research in the judicial voting behavior literature is a clearer understanding of how voters in

The authors would like to thank the editor and the anonymous reviewers of American Review of Politics for their helpful comments and advice on earlier versions of this paper. The authors would also like to thank Dr. Philip Marshall and The Center for Public Service at Texas Tech University for funding the survey as well as the Earl Survey Research Lab at Texas Tech for conducting this survey. An earlier version of this article was presented at the 2011 annual meeting of the Southern Political Science Association. The authors' names appear in alphabetical order.

MARK J. MCKenzIE is an assistant professor of political science at Texas Tech University. CynTHIA R. RUGELEY is an assistant professor of political science at Texas Tech University. MichaEL A. UngER is an assistant professor of political science at Ramapo College of New Jersey.

The American Review of Politics, Vol. 33, Winter, 2012-2013: 295-321

(C)2012 The American Review of Politics 
judicial elections weigh partisan cues versus campaign message cues based on experience and issues. Some judicial issues can involve rather complicated legal concepts, but few studies have investigated how voters' levels of political sophistication might affect the intake of these issues and hence influence voter choice in judicial elections.

This paper examines two central questions: 1) how do voters in judicial elections respond to issue salience and experience in the face of competing considerations of partisanship, and 2) how does political sophistication mediate voter responses to these considerations? To accomplish this, we draw on an experiment in a 2009 statewide telephone poll of registered voters in Texas that provided respondents with information on hypothetical judicial candidates. While we know a good amount about voting in judicial elections at the aggregate level, our focus is on the individual level where existing research is limited due to a previous lack of appropriate data. We find that individuals use party identification as a short-cut when voting for a judicial candidate, even when they have other informational cues about the candidate. Many of our respondents claimed in the survey that partisanship should not play a role in the decision calculus, yet we found that partisan cues operate as powerful influences on the vote. These findings suggest that in partisan judicial election systems, even when voters are provided with information about a candidate's issue positions or qualifications and experience for office, a certain group of voters are resistant to this additional information, choosing instead to cast a partisan vote. In addition, we look at how the salience of a popular judicial campaign issue - frivolous lawsuitsaffects voter decisions. We find that the salience of this issue only matters to voters with high levels of political sophistication because those voters have both the ability and the desire to process and understand this potentially complex legal issue.

The findings in this study have important implications for how we observe voter behavior in a politicized judicial election environment. While many legal scholars, organizations like the American Judicature Society, and media accounts have voiced concerns about both partisan elections and an increasingly politicized judicial environment over the last three decades (see, for example, the citations in endnote 1), Texas already possesses a politicized supreme court election environment with partisan elections (Cheek and Champagne 2005). Thus, the state in our study provides an ideal microcosm for how voters might behave in a politicized partisan judicial election environment. Our findings about the behavior of Texas voters have larger relevance for understanding how voters in other partisan judicial states might behave.

Our study also provides important clues for how voters with different levels of political knowledge (or political sophistication) process the cam- 
paign information they receive in judicial elections. Issues in judicial campaigns can often involve complex legal issues and campaign language that differs from other types of elections. Thus, the amount of political knowledge voters possess should affect their ability to receive and act on judicial campaign messages (Carmines and Stimson 1980).

\section{Factors that Effect Judicial Elections}

Historically, judicial elections have been sleepy affairs, with minimal amounts of campaign spending (Dubois 1979, 1980; Johnson et al. 1978). Traditional style judicial campaigns tend to impart little in the way of substantive information on issues to the voters (Abbe and Herrnson 2002; Arbour and McKenzie 2010). Consequently, voters tend to lack awareness of issues and candidates in judicial races (Champagne and Thielemann 1991; Lovrich et al. 1989; McKnight et al. 1978). These historical characteristics of judicial campaigns are not much different from other low-salience elections.

In recent decades, the election environment has been changing in campaigns for state supreme court justice to more politicized campaigns, what some judicial scholars call the "New Style" campaigns (Hojnacki and Baum 1992; Gibson 2008). These politicized judicial campaigns feature increased campaign spending, more competitive elections, and a greater emphasis by campaigns on controversial issues and negative politics (Gibson 2008). From a legal standpoint, judicial candidates are now freer to focus on substantive policy issues or negative attacks after the U.S. Supreme Court struck down some state restrictions on judicial campaign speech as a violation of the First Amendment. ${ }^{2}$ In some respects, the rhetoric of these judicial campaigns have the potential to look like campaigns for other offices. Certainly, previous studies indicate that voters behave similarly in judicial elections as compared to other low salience elections. What's less understood is how voters react to campaign claims and issues positions in light of partisan cues, and whether political sophistication mediates the process. In our study, we focus on four factors that often effect low salience elections: partisanship; candidate experience; issue salience; and the mediating role of political sophistication. Judges in partisan elections are subjected to different electoral forces when compared to other judicial selection systems (Hall 2001). As Brace and Hall (1995; and Hall and Brace 1989) and others have shown, from a neo-institutional perspective, judges' behaviors in state courts are very much constrained by their institutional settings. This constraint, of course, is due in part to the nature of how voters are channeled by the electoral system in the state. Our study contributes further to our understanding of these linkages between judicial behavior and electoral forces by 
experimentally examining voter reaction to the presentation of candidates and issues in partisan and nonpartisan contexts.

In considering how issue salience and political sophistication can affect voter behavior in judicial elections, it is useful to draw on principles from the larger voting behavior literature, particularly research on political sophistication, partisanship, and issue voting. Druckman argues that candidates can prime issues or images "caus[ing] people to then base their evaluations on" these factors (Druckman 2004, 578). In his study on the 2004 Minnesota Senate election, he found that the most attentive voters based their voting decisions on the issues emphasized during the campaign (Druckman 2004). Tort reform is a popular issue in Texas judicial elections, and judicial experience is an image frequently touted by judicial candidates. In our study, we examine how priming voters with the issue of tort reform or an image of experience affects their voting evaluation in the face of competing partisan cues.

Voters who are more politically sophisticated respond to certain types of policy issues differently (e.g., Carmines and Stimson 1980). Those who possess more political information will assess politics differently from those who do not (Althaus 1998; Bartels 1996; Blais and Turgeon 2004; Zaller 1992).

The potential for complexity in discussions of legal issues in judicial campaigns also means that some voters may respond differently to the exposure of campaign information based on their level of political sophistication. Evidence from studies in political sophistication indicate that the more politically sophisticated, when faced with complicated policy issues or policy arguments, are more likely to understand such arguments or issues and respond accordingly (Carmines and Stimson 1980; Cobb and Kuklinski 1997; McKenzie 2009). In judicial campaigns, some legal issues like abortion or gay marriage seem relatively straightforward. Many other types of legal issues, however, are more complicated to understand. This complexity raises the possibility that only the more politically sophisticated voter will effectively internalize information on certain judicial campaign issues and then act on that information.

There is some evidence that politically aware voters behave similarly in the context of judicial elections as in other low salience elections (Baum 1987b; Klein and Baum 2001; Baum and Klein 2007; Rock and Baum 2010). For example, the effect of campaign spending was most pronounced among voters with higher levels of political knowledge. In addition to partisanship, politically aware voters will use other information in high visibility judicial elections like ideology and issue positions (Rock and Baum 2010; see also Baum and Klein 2007). In other words, politically sophisticated 
voters in judicial elections appear to respond to issues in ways that are similar to other low-information contests.

Other than the research done by Baum and his colleagues in the semipartisan state of Ohio, ${ }^{3}$ few judicial studies have tried to disentangle the effects of issues from partisanship at the individual level, particularly in partisan judicial election systems. Campaign effects in judicial election studies have mostly been measured in terms of dollars spent rather than issues emphasized. Nevertheless, there are some other notable studies in the literature that help form a picture of how issues might operate on voter behavior.

Judges in retention elections, where campaigning is usually sparse, almost always win retention or reelection (Aspin 1998). But some indirect and anecdotal evidence suggest that issues can have an effect in these elections. In one study, judicial scholars found that vote share for judges can decrease among voters who have more information about the incumbent candidate (Griffin and Horan 1983). Moreover, anecdotal evidence from the recent 2010 Iowa contests - in which all state supreme court justices up for retention lost their election, presumably due to their decision supporting gay marriage - as well as other high visibility retention losses (Reid 1999; Wold and Culver 1987) suggests that issues have the potential to impact voter decisions in a way akin to races for other electoral offices, particularly if voters are more informed or if issues take on a partisan character.

Since voters are not always aware of issues in low salience elections, information shortcuts like partisan identification and candidate experience should be particularly influential in these races. When information is scarce, voters rely on low information shortcuts. These shortcuts can be a candidate's partisanship, gender, race, or a candidate's experience based on occupational cues that serve as proxies for competence and qualifications (McDermott 1997, 1998, 2005). Voters associate political parties with particular issues and ideologies, and weigh their own attitudes against those that they associate with parties (e.g., Campbell et al. 1960; Conover and Feldman 1989; Nelson and Kinder 1996).

The evidence of partisan voting in all types of judicial election systems has been well-documented. Partisanship has been recognized as an important determinant of the vote in partisan election systems (e.g., Dubois 1979, 1980), "semi" partisan election systems such as Ohio (Baum 1987a; Klein and Baum 2001; Rock and Baum 2010) and even nonpartisan and merit selection systems (Squire and Smith 1988).

Candidate experience is an information shortcut that should be particularly relevant to judicial voters, just as it is in other kinds of elections (Ansolabehere et al. 2006). The job of a judge requires specialized knowledge in the law, and thus a candidate's previous judicial or legal experience 
would be a reliably accurate heuristic that voters could employ. In his examination of California state superior court elections, Dubois (1984) found that candidates who were incumbents or who listed their occupation on the ballot as a judge on another court (such as municipal court) fared much better among voters as compared to candidates with less judicial experience. The evidence of the high rate of retention of incumbents in merit selection races also suggest that voters are predisposed to vote for someone with experience, all else being equal (Aspin 1999). On the other hand, Klein and Baum's (2001) study of Ohio's semi-partisan system found that partisan information, not incumbency, had large effects on voter behavior. More recently, Hall and Bonneau (2006; see also Bonneau and Hall 2009) establish the significant effects of judicial experience on voters in state supreme court elections by finding that quality challengers with prior judicial experience perform better in terms of vote share against incumbents. The extant literature tells us very little about how voters weigh the salience of experience against partisan cues found in partisan judicial elections.

We build on the judicial voting behavior literature by investigating the force of partisanship versus other factors such as judicial experience or policy issues. We also examine the role that political sophistication could play in elections where voters are tasked with consuming legal issues that can sometimes appear esoteric and complicated. By focusing on the partisan election system of Texas, we address the question of whether the rise of politicized judicial campaigning and substantive policy discussion has any impact on the voting public, or whether partisanship remains the overarching influence on voters.

\section{Data and Design}

In this study, we take advantage of a statewide telephone poll of registered voters in Texas, conducted between July 8, 2009, and August 3, 2009, by the Earl Survey Research Lab at Texas Tech University, whose clients consist of university communities, businesses and local government. ${ }^{4}$ The telephone survey includes a random sample of 502 registered voters in Texas and has a sampling error of 4.38 percent. The survey covered attitudes toward the Texas judicial system, questions measuring political knowledge (including two questions about the Texas judiciary), demographic characteristics and political attributes, as well as an experimental vignette about a hypothetical judicial candidate running for state supreme court.

Selecting Texas for this analysis has some positive and negative consequences worth discussing. Texas is the second most populous state in the country making understanding the dynamics of judicial elections important because of its size. Texas is also frequently used as an example of politicized 
judicial elections (see McKenzie and Unger 2011). With fears that judicial elections are becoming "Texas-style" (Schultz 2006), it is important to begin understanding how voters in this state respond to politicized campaigns to determine whether fears of judicial election opponents are justified. The state also features partisan elections, which are not as extensively studied as non-partisan or semi-partisan judicial elections. While we do not contend that Texas is generalizable to all other states, it provides insight into other states with partisan elections such as Louisiana and Alabama.

\section{Voter Campaign Experiment}

In order to test for voter considerations of partisanship vis-à-vis the salience of policy issues or experience, we embedded an experiment consisting of six vignettes into the survey. Individuals were randomly assigned to one of these six treatment groups. Each respondent was given a description of a hypothetical candidate, James Smith, running for Texas Supreme Court. The vignettes varied in two important ways - the partisanship of Smith (Republican, Democrat, or no party identification listed for the candidate); and the campaign theme being promoted by Smith (explicitly promising to stop frivolous lawsuits or a description of Smith's judicial and legal experience). By having our candidate explicitly promise to rule in a certain way on the politically charged topic of tort reform in three of our six vignettes, we hoped to inject characteristics of politicized campaigning into our experiment. The experimental vignettes given to respondents were as follows, with the percent of subjects assigned to each group in parentheses:

Group 1: James Smith is running for the Texas Supreme Court. He promises to stop frivolous lawsuits if he wins a seat on the court (16 percent).

Group 2: James Smith, a Republican, is running for the Texas Supreme Court. He promises to stop frivolous lawsuits if he wins a seat on the court (16 percent).

Group 3: James Smith, a Democrat, is running for the Texas Supreme Court. He promises to stop frivolous lawsuits if he wins a seat on the court (17 percent).

Group 4: James Smith is running for the Texas Supreme Court. He has 20 years of legal experience, including ten years as a trial judge (18 percent). 
Group 5: James Smith, a Republican, is running for the Texas Supreme Court. He has 20 years of legal experience, including ten years as a trial judge (17 percent).

Group 6: James Smith, a Democrat, is running for the Texas Supreme Court. He has 20 years of legal experience, including ten years as a trial judge (17 percent).

Other than the above experimental manipulations, each respondent completed identical surveys. ${ }^{5}$

We chose the issue of frivolous lawsuits because tort reform has been a recurring theme in judicial campaigns in Texas over the last two decades. In fact, powerful state interest groups such as Texans for Lawsuit Reform were active on this issue in a recent "contentious" 2010 Republican primary election between Debra Lehrmann and Rick Green for a seat on the Texas Supreme Court (Ramsey and Smith 2010). In the 2011 session, the Texas Legislature passed a loser-pays law in an effort to decrease the number of frivolous lawsuits. As this issue continues to be in the spotlight and long on the policy agenda in Texas state politics, our experimental vignettes present a realistic issue with a fair degree of salience to Texas judicial voters. Thus, we have some measure of external validity for our experiment. We employ the language of "frivolous lawsuits" as an alternative to the term "tort reform" because that is the wording most often used by candidates as an informal means for addressing the issue of tort reform. Tort reform is also a good issue to choose because it is evident in many races across other states as well, as business groups often inject the issue into judicial elections (Bonneau 2007; Canes-Wrone and Clark 2009). Canes-Wrone and Clark (2009, 35 ) point out that "[b]usiness and regulatory issues have . . . played prominently in judicial races over the past several decades."

To measure the effect of issue salience versus partisanship, we vary the partisanship of the candidate in the three vignettes containing the issue of frivolous lawsuits. The other three vignettes contain an experience cue so that we can compare the effects of partisanship versus a cue regarding a candidate's experience.

We measured the respondents' levels of political knowledge through five survey questions, relying primarily on principles for measuring political sophistication developed by Delli Carpini and Keeter (1996). ${ }^{6}$ The five questions included two questions about national government and three questions specific to Texas government. The questions covered knowledge of political parties, identification of politicians in government, and the processes of the government. Two of the questions dealt with Texas courts (asking respondents to identify the chief justice from three names given and 
to correctly identify the type of selection system Texas has for its judges). The questions discouraged "don't know" as an answer by not explicitly including it as an option.

\section{Two Models of Judicial Voting}

Keeping in mind the aforementioned principles of our experiment, we constructed two models of judicial voting. The frivolous lawsuits model examines the impact of partisanship against a frequently raised judicial election issue. The judicial experience model examines the impact of partisanship against the traditional judicial campaign themes of experience and qualifications. The dependent variable in both models is based on the question asked directly after the experimental vignette, "How likely is it that you would vote for this candidate." The question offered respondents four choices and we collapsed those four choices down to a binary dependent variable (vote for). Given the nature of our dependent variable, we employ logistic regression to analyze our model.

A description of independent variables employed in our models is provided in Table 1. In both models, we construct dummy variables to account for each of the experimental groups that the respondents fell into, and in each model, the group of respondents who received the Republican prompt operated as the comparison or baseline group. We also included a measure of the respondent's partisanship, based on a seven-point scale, where 1 equals a strong Republican and 7 equals a strong Democrat. ${ }^{7}$ To measure voter responses to the partisan cues of candidates, we interact partisanship with group.

In the frivolous lawsuits model (Model 1), we accounted for issue effects by asking respondents in the survey to gauge the importance of the problem of frivolous lawsuits. Those who view the issue as very important should be more likely to be enticed into supporting a candidate who promises to stop frivolous lawsuits when compared to respondents who do not view the issue as particularly important. Moreover, the literature in judicial elections and the literature on voting in general suggest that the more politically sophisticated voters are likely to take in and act upon issues (particularly complicated issues) in a manner consistent with their views on those issues. All respondents in the first three treatment groups were given prompts stating that the candidate wanted to stop frivolous lawsuits. To account for whether the most sophisticated respondents acted differently from less sophisticated respondents with regard to the information given to them in relation to their own issue positions, we interacted respondents' views on frivolous lawsuits with our measure of political sophistication. ${ }^{8} \mathrm{We}$ also included political sophistication as a separate control measure (see Table 1). 
Table 1. Variable Descriptions

\begin{tabular}{ll}
\hline Variable Name & Variable Description \\
\hline Vote for & $\begin{array}{l}\text { This is the Dependent Variable: } 1 \text { is a respondent indication } \\
\text { to vote for our candidate James Smith, and } 0 \text { is a vote } \\
\text { against. }\end{array}$
\end{tabular}

Sophistication

Our measure of political sophistication (or political knowledge), based on 5 questions, and constituting an additive scale from 0 to 5 , where 0 represents a respondent who got no questions correct.

Respondent PID

The respondent's party identification. This is a seven point party identification scale, where 1 equals a strong Republican and 7 equals a strong Democrat.

No Judge PID

Democratic Judge

This dichotomous variable refers to treatment groups 1 and 4 , where our candidate in the vignette was not identified with a partisan label.

This dichotomous variable refers to treatment groups 3 and 6 , where our judicial candidate was identified to respondents as being a Democrat. (The two treatment groups that contained the Republican judge operated as our baseline measures in our two models.)

NoJudgePID*RespPID This multiplicative variable refers to our interaction of treatment groups 1 or 4 (where the candidate had no party label) with the respondent's party identification. In model 1 , we interact group 1 , whereas in model 2 the interaction is with group 4.

DemJudge*RespPID This multiplicative variable refers to our interaction of treatment groups 3 or 6 (where the candidate was identified as a Democrat) with the respondent's party identification. In models 1 , we interact group 3, whereas in models 2 the interaction is with group 6 .

Demographic Variables: We include several dichotomous demographic variables. Age, Black, Latino, Gender Age is simply the age of the respondent. For gender, women equal 1 , men 0 . Being Black or Latino equal 1 in the models.

\section{Model 1 (Frivolous Lawsuits Model)}

Frivolous

Sophistication*Frivolous
Below are two variables used in Model 1 based on an analysis of treatment groups 1-3.

A three point scale, where 1 means the respondent said the issue was not important at all, and 3 meant the respondent thought the issue was very important

This multiplicative variable interacts the respondent's political sophistication score with her attitudes on the importance of the issue of frivolous lawsuits. 
Table 1. Variable Descriptions (continued)

\begin{tabular}{|c|c|}
\hline Variable Name & Variable Description \\
\hline $\begin{array}{l}\text { Model } 2 \text { (Judicial } \\
\text { Experience Model) }\end{array}$ & $\begin{array}{l}\text { Below are three variables used in Model } 2 \text { based on an } \\
\text { analysis of treatment groups } 4-6 \text {. }\end{array}$ \\
\hline Experience & $\begin{array}{l}\text { A four point scale, where } 1 \text { equals a respondent who } \\
\text { strongly disagreed that candidates for state supreme court } \\
\text { should have prior judicial experience and } 4 \text { equals a re- } \\
\text { spondent who strongly agreed that a supreme court candi- } \\
\text { date should have prior judicial experience. }\end{array}$ \\
\hline Experience*Sophistication & $\begin{array}{l}\text { This multiplicative variable refers to our interact of respon- } \\
\text { dents attitudes about prior judicial experience in a judicial } \\
\text { candidate with the respondent's level of sophistication }\end{array}$ \\
\hline Prominent Lawyer & $\begin{array}{l}\text { A four point scale, where } 1 \text { equals a respondent who } \\
\text { strongly disagreed that candidates for state supreme court } \\
\text { should be prominent lawyers and } 4 \text { equals a respondent } \\
\text { who strongly agreed with that statement. }\end{array}$ \\
\hline
\end{tabular}

In addition to the above measures, we included several demographic measures in both our models, including whether the respondent was AfricanAmerican, Latino, or female (referred to as gender in the tables). We also accounted for the age of the respondent.

In the judicial experience model (Model 2), all the variables employed are the same as the first model except for those relating to frivolous lawsuits. Since the vignettes for groups four, five, and six involve a supreme court candidate with previous judicial experience, we include a variable based on one of our survey questions that asks respondents whether they agreed with the statement that supreme court candidates should have prior judicial experience. We expect voters who either agree or strongly agree with this statement may be more predisposed to support our hypothetical candidate in the vignette, since he has 10 years experience as a trial judge (and 20 years experience as an attorney). We make this hypothesis based on previous findings by Bonneau and Hall (2009) indicating that challengers with trial court experience running for state supreme court receive more votes against an incumbent Supreme Court justice as compared to other types of challengers. Again, we interact experience with political sophistication to measure whether there are differences in how respondents internalized the information provided to them on the candidate. Finally, the judicial experience model 2 includes a variable that measures whether respondents believe that supreme court candidates should be "prominent lawyers." 


\section{Summary Results of the Poll}

Before getting to the results of our multivariate analysis, we believe it is instructive to examine the summary questions of our primary variables of interest. Table 2 sets forth the percentages of support among the various experimental groups accorded to James Smith.

As is evident from the treatment groups, the candidate with no party labels (in groups 1 and 4) did not obtain as much support as the candidate identified as Republican. Thus, just from examining the summary statistics, it would appear that some voters were particularly receptive to the partisan labels. Table 3 presents our respondents' views of the importance of the legal policy issue of frivolous lawsuits as well as their attitudes about candidate characteristics of experience and qualifications. Most of our respondents either agreed or strongly agreed that state supreme court candidates should have previous experience as judges.

The percentage of respondents who said the issue of frivolous lawsuits in Texas was "very important" was 45 percent. Another 40 percent said the issue was only "somewhat important," and 12 percent said the issue was "not important at all."

\section{Table 2. Percentage Support/Opposition for Candidate Among Experimental Treatments}

\begin{tabular}{|c|c|c|c|}
\hline Treatment Group & Support for Smith & Opposition to Smith & Don't Know \\
\hline $\begin{array}{l}\text { Group } 1 \text { No party, } \\
\text { frivolous lawsuits }\end{array}$ & $64 \%(50)$ & $26 \%(20)$ & $10 \%(8)$ \\
\hline $\begin{array}{l}\text { Group } 2 \text { Republican, } \\
\text { frivolous lawsuits }\end{array}$ & $70 \%(53)$ & $21 \%(16)$ & $9 \%(7)$ \\
\hline $\begin{array}{l}\text { Group } 3 \text { Democrat, } \\
\text { frivolous lawsuits }\end{array}$ & $58 \%(47)$ & $31 \%(25)$ & $11 \%(9)$ \\
\hline $\begin{array}{l}\text { Group } 4 \text { No party, } \\
\text { experience }\end{array}$ & $59 \%(53)$ & $15 \%(13)$ & $27 \%(24)$ \\
\hline $\begin{array}{l}\text { Group } 5 \text { Republican, } \\
\text { experience }\end{array}$ & $68 \%(56)$ & $20 \%(16)$ & $12 \%(10)$ \\
\hline $\begin{array}{l}\text { Group } 6 \text { Democrat, } \\
\text { experience }\end{array}$ & $62 \%(51)$ & $26 \%(21)$ & $12 \%(10)$ \\
\hline
\end{tabular}




\section{Table 3. Respondent Attitudes toward Frivolous Lawsuits and Candidate Experience}

\section{Candidate Experience}

Question: "Supreme Court candidates should have previous experience as judges."

\begin{tabular}{|c|c|c|c|c|c|}
\hline $\begin{array}{c}\text { Strongly } \\
\text { Agree }\end{array}$ & Agree & $\begin{array}{l}\text { Neither } \\
\text { Agree Nor } \\
\text { Disagree }\end{array}$ & Disagree & $\begin{array}{l}\text { Strongly } \\
\text { Disagree }\end{array}$ & $\begin{array}{l}\text { Don't } \\
\text { Know }\end{array}$ \\
\hline $32 \%(158)$ & $60 \%(303)$ & $2 \%(8)$ & $6 \%(30)$ & $<1 \%$ & $<1 \%$ \\
\hline
\end{tabular}

Importance of Issue of Frivolous Lawsuits

Question: "Some say frivolous lawsuits are a problem in Texas. Others say they are not a problem. How important is the issue of frivolous lawsuits to you?"

$\begin{array}{cccc}\text { Very } & \text { Somewhat } & \text { Not Important } & \\ \text { Important } & \text { Important } & \text { At All } & \text { Don't Know } \\ 45 \%(224) & 40 \%(200) & 12 \%(61) & 3 \%(17)\end{array}$

$\mathrm{N}=502$ total survey. Some percentages may not add up to $100 \%$ due to rounding of decimal points. Number of respondents are listed in parentheses.

\section{Results of the Multivariate Analyses}

\section{Model 1: Stopping Frivolous Lawsuits}

Table 4 reports results of our two logit analyses. Panel 1 reports variables and results of the frivolous lawsuits model, while Panel 2 reports results of the judicial experience model. We begin our multivariate analysis by examining the frivolous lawsuit model (Table 4, Panel 1). We are interested in whether the influence of the issue treatment is different as respondents become more politically knowledgeable, and whether support for partisan candidates with issue positions is conditioned by the political identification of the respondent. Model 1 includes two interactions: 1) testing whether a subject's party identification conditions his/her support for a partisan judicial candidate with issue positions; and 2) how issue salience influences the likelihood of voting for our judicial candidate James Smith as the political knowledge of voters varies. If issues are important, we would expect a stronger influence among voters who consider it very important relative to those who consider it less so. Also, if political sophistication has no influence on issue voting, then we would expect that there would be no significant finding at any level of political sophistication. 
Table 4. Logit Regression Estimates Showing Effects of Frivolous Lawsuits and Experience on Voting Probabilities

(ependent Variable is coded 1 for a yes vote and 0 otherwise)

\begin{tabular}{|c|c|c|c|}
\hline Variable & $\begin{array}{c}\text { Model } \\
\text { Frivolous Lawsuits }\end{array}$ & Variable & $\begin{array}{c}\text { Model } \\
\text { Experience }\end{array}$ \\
\hline Frivolous Issue & $\begin{array}{l}-1.12 \\
(0.703)\end{array}$ & Experience & $\begin{array}{l}-.021 \\
(.671)\end{array}$ \\
\hline Sophistication & $\begin{array}{l}-0.993^{*} \\
(0.527)\end{array}$ & Sophistication & $\begin{array}{l}0.78 \\
(.805)\end{array}$ \\
\hline Respondent PID & $\begin{array}{l}-0.447 * * \\
(0.195)\end{array}$ & Prominent Lawyer & $\begin{array}{c}0.239 \\
(0.184)\end{array}$ \\
\hline No Judge PID & $\begin{array}{l}-1.639 \\
(1.084)\end{array}$ & Respondent PID & $\begin{array}{l}-0.634 * * * \\
(0.182)\end{array}$ \\
\hline Democratic Judge & $\begin{array}{l}-4.217 * * * \\
(1.046)\end{array}$ & No Judge PID & $\begin{array}{l}-.99 \\
(1.277)\end{array}$ \\
\hline Sophistication*Frivolous & $\begin{array}{l}0.484^{* *} \\
(0.221)\end{array}$ & Democratic Judge & $\begin{array}{c}-2.65 * * \\
(1.057)\end{array}$ \\
\hline NoJudgePID*RespPID & $\begin{array}{c}0.324 \\
(0.247)\end{array}$ & Experience* sophistication & $\begin{array}{l}-0.212 \\
(0.235)\end{array}$ \\
\hline DemJudge*RespPID & $\begin{array}{l}0.934 * * * \\
(0.241)\end{array}$ & NoJudgePID*RespPID & $\begin{array}{c}0.338 \\
(0.255)\end{array}$ \\
\hline Age & $\begin{array}{l}0.014 \\
0.013)\end{array}$ & Dem Judge*RespPID & $\begin{array}{l}0.574 * * * \\
(0.219)\end{array}$ \\
\hline Black & $\begin{array}{l}-1.458^{*} \\
(0.823)\end{array}$ & Age & $\begin{array}{l}-0.022 * \\
(0.011)\end{array}$ \\
\hline Latino & $\begin{array}{l}-0.919 \\
(0.622)\end{array}$ & Black & $\begin{array}{l}-0.491 \\
(0.587)\end{array}$ \\
\hline Gender & $\begin{array}{l}0.33 \\
(0.412)\end{array}$ & $\begin{array}{l}\text { Latino } \\
\text { Gender }\end{array}$ & $\begin{array}{c}0.061 \\
(0.696) \\
0.41 \\
(0.409)\end{array}$ \\
\hline Constant & $\begin{array}{l}5.919 * * * \\
(2.111)\end{array}$ & Constant & $\begin{array}{c}4.333^{*} \\
(2.544)\end{array}$ \\
\hline$N$ & 193 & $N$ & 195 \\
\hline $\begin{array}{l}\% \text { Percent Correctly } \\
\text { Predicted }\end{array}$ & 75.65 & $\begin{array}{l}\% \text { Percent Correctly } \\
\text { Predicted }\end{array}$ & 79.49 \\
\hline $\begin{array}{l}\text { Proportional Reduction } \\
\text { in Error }\end{array}$ & $12.96 \%$ & $\begin{array}{l}\text { Proportional Reduction } \\
\text { in Error }\end{array}$ & 11.11 \\
\hline Log-Likelihood & -96.264 & Log-Likelihood & -88.11 \\
\hline $\operatorname{LR}(12) X^{2}$ & $36.28 * * *$ & $\mathrm{LR} \mathrm{X}^{2}$ & $34.45^{* * *}$ \\
\hline \multicolumn{4}{|c|}{$\begin{array}{l}* \mathrm{p}<.10 ; * * \mathrm{p}<.05 ; * * * \mathrm{p}<.01 \\
\text { The dependent variables for both models are coded } 1 \text { when the respondent is likely to vote for the } \\
\text { judicial candidate (James Smith) and } 0 \text { otherwise. The comparison group for both models is the } \\
\text { Republican version of the judicial candidate. The models are estimated using logistic regression with } \\
\text { standard errors in parentheses. }\end{array}$} \\
\hline
\end{tabular}


Model 1 in Table 4 reports that the coefficient for frivolous lawsuit issue is negative and lacks statistical significance. This finding indicates that issue importance has little effect on the probability of supporting the candidate among those voters with the lowest level of political knowledge. Figure 1A illustrates, however, that as political knowledge increases, respondents' attitudes toward the issue of frivolous lawsuits becomes a significant factor influencing their voting decision at a level of three on our political sophistication scale. Citizens with a greater interest in frivolous lawsuits are more likely to support the candidate relative to those who consider it less important. ${ }^{10}$ Because logit coefficients have little substantive meaning, we calculated predicted probabilities of the respondent voting for the candidate at all levels of political sophistication and among those voters who said frivolous lawsuits was a very important issue, and also those who said the issue was not important at all (Table 5). Among respondents scoring a three on our sophistication scale and who also consider frivolous lawsuits an important issue, we predicted there was a .95 probability they would support the candidate (Table 5). Among those voters with the highest level of political sophistication and who consider the issue important, the probability they would support the candidate was .98 (Table 5). For voters who do not consider the issue important, the effect is inverted. As political sophistication increases, the probability of voting for the candidate decreases. It seems reasonable to surmise that the lower sophisticates did not internalize or understand the political significance of campaign language supporting an end to frivolous lawsuits, which is why there is no differentiation in their response to the prompt. After all, no one supports frivolous lawsuits. However, higher-level sophisticates were probably better able to understand that this particular campaign rhetoric involved "code words" related to notions of tort reform and the proper balance of consumer rights versus business concerns. The more knowledgeable citizens are among those who are either most able or willing to sift through political information and make decisions consistent with their own policy beliefs, particularly with respect to issues that are complex (Cobb and Kuklinski 1997; McKenzie 2009). While "stopping frivolous lawsuits" is a popular refrain among conservative judicial candidates in Texas, our findings suggest that such rhetoric, if it reaches the voters, is only affecting those voters with the highest levels of political sophistication. In addition, individuals assigning the issue low importance appear to be "turned off" by the promise to stop frivolous lawsuits suggesting this particular rhetoric does not possess universal benefits for judicial candidates even though few people admit to supporting frivolous lawsuits.

Turning to support for partisan judicial candidates, Panel 1 in Table 4 shows that there is no statistically significant difference between voting probabilities for a judge not identified by a partisan label (No Judge PID) 


\section{Figure 1}

\section{Panel A: Issue Salience and Political Knowledge}

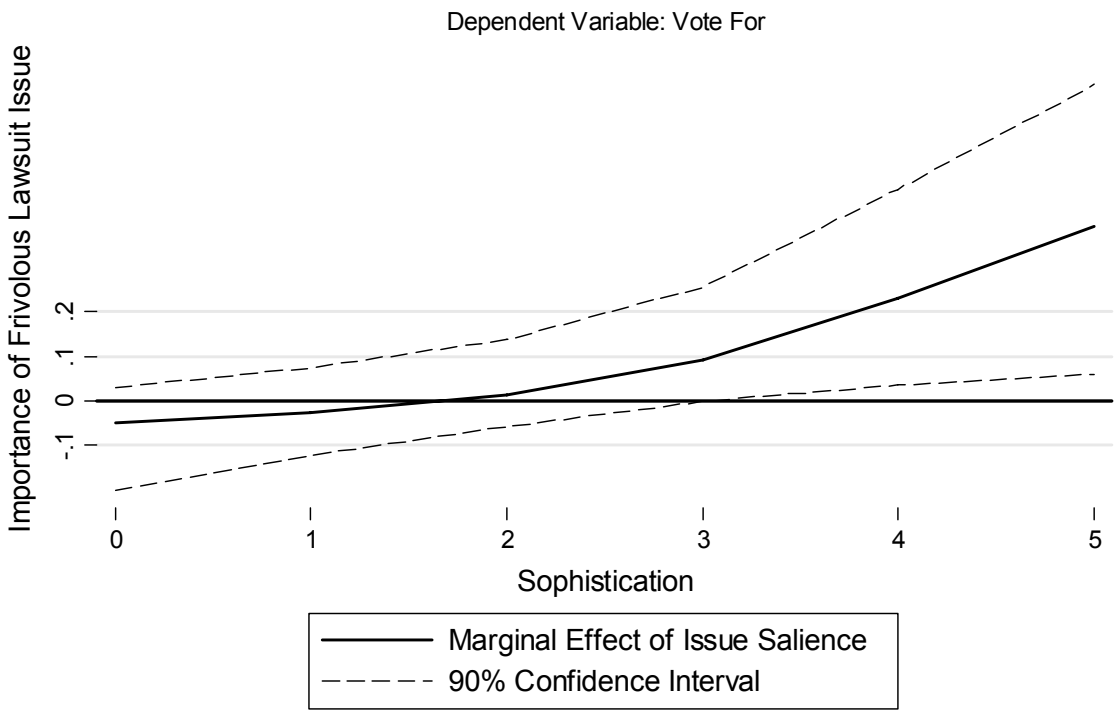

Panel B: Judicial Experience and Political Knowledge

Dependent Variable: Vote For

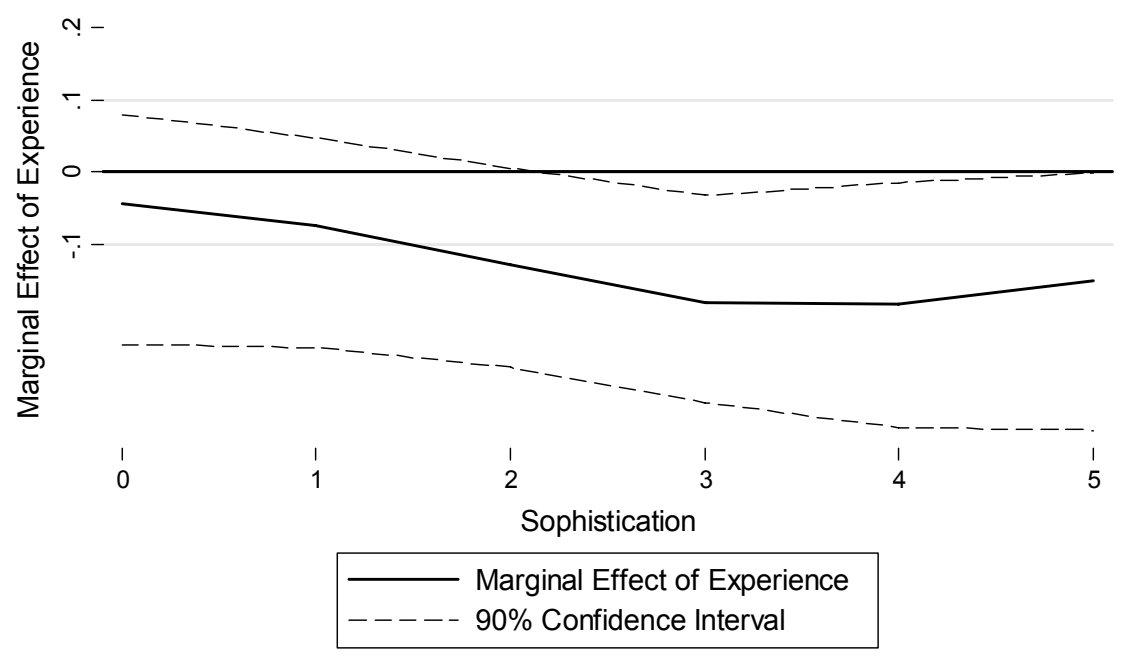




\section{Figure 1 (continued)}

\section{Panel C: Democratic Judge and Respondent PID}

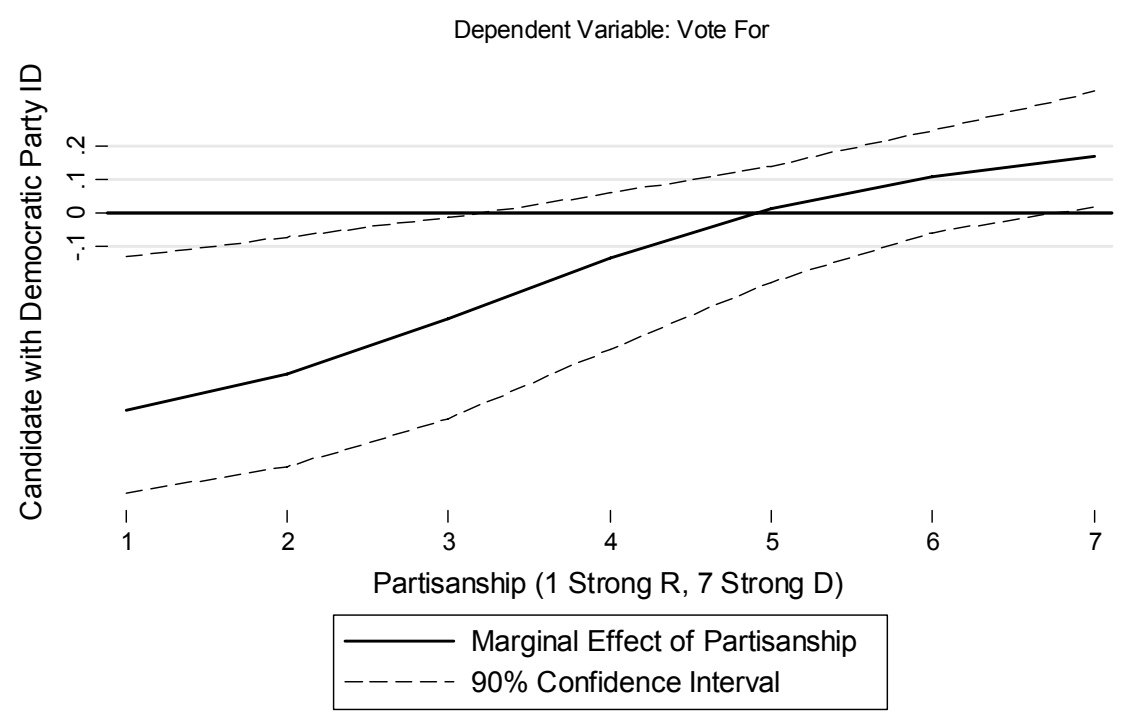

Figure 1A shows the marginal effects of the importance of frivolous lawsuits as an issue on probability of voting for a judicial candidate as respondent political knowledge increases from the lowest level of 0 to the highest of 5. Panel B graphically shows the effect of judicial experience on the probability of supporting a judge as levels of respondent political knowledge increases from the lowest level of 0 to the highest level of 5. Panel C illustrates the effect of being a Democrat on probability of voting for a judicial candidate as respondent political identification increases from strong Republican (coded 1) to strong Democrat (coded 7). The solid line is the margin effect at different levels of the mediating variable and the dashed lines are $10 \%$ confidence intervals. When the confidence intervals are on the same side of 0 , the effect is statistically significant. 
Table 5. Predicted Probabilities of Voting for a Judicial Candidate

\section{Model 1: Frivolous Lawsuits}

\begin{tabular}{|c|c|c|c|c|c|c|c|}
\hline \multirow[b]{2}{*}{ Issue Salience } & \multicolumn{7}{|c|}{ Political Knowledge ${ }^{a}$} \\
\hline & $\begin{array}{c}0 \\
\text { (Low) }\end{array}$ & 1 & 2 & 3 & 4 & $\begin{array}{c}5 \\
\text { (High) }\end{array}$ & \\
\hline $\begin{array}{l}\text { Issue Importance } \\
\text { (High) }\end{array}$ & .84 & .89 & .93 & .95 & .97 & .98 & \\
\hline \multirow[t]{2}{*}{ (Low) } & .98 & .96 & .94 & .90 & .84 & .77 & \\
\hline & \multicolumn{7}{|c|}{ Respondent Party Identification ${ }^{b}$} \\
\hline $\begin{array}{l}\text { Judicial Candidate } \\
\text { Party ID }\end{array}$ & $\begin{array}{c}1 \\
\text { (Strong R) }\end{array}$ & 2 & 3 & $\begin{array}{c}4 \\
\text { (Ind) }\end{array}$ & 5 & 6 & $\begin{array}{c}7 \\
\text { (Strong D) }\end{array}$ \\
\hline Democratic Judge & .38 & .50 & .62 & .72 & .81 & .87 & .92 \\
\hline Republican Judge & .94 & .91 & .87 & .81 & .73 & .63 & .52 \\
\hline
\end{tabular}

Model 2: Experience

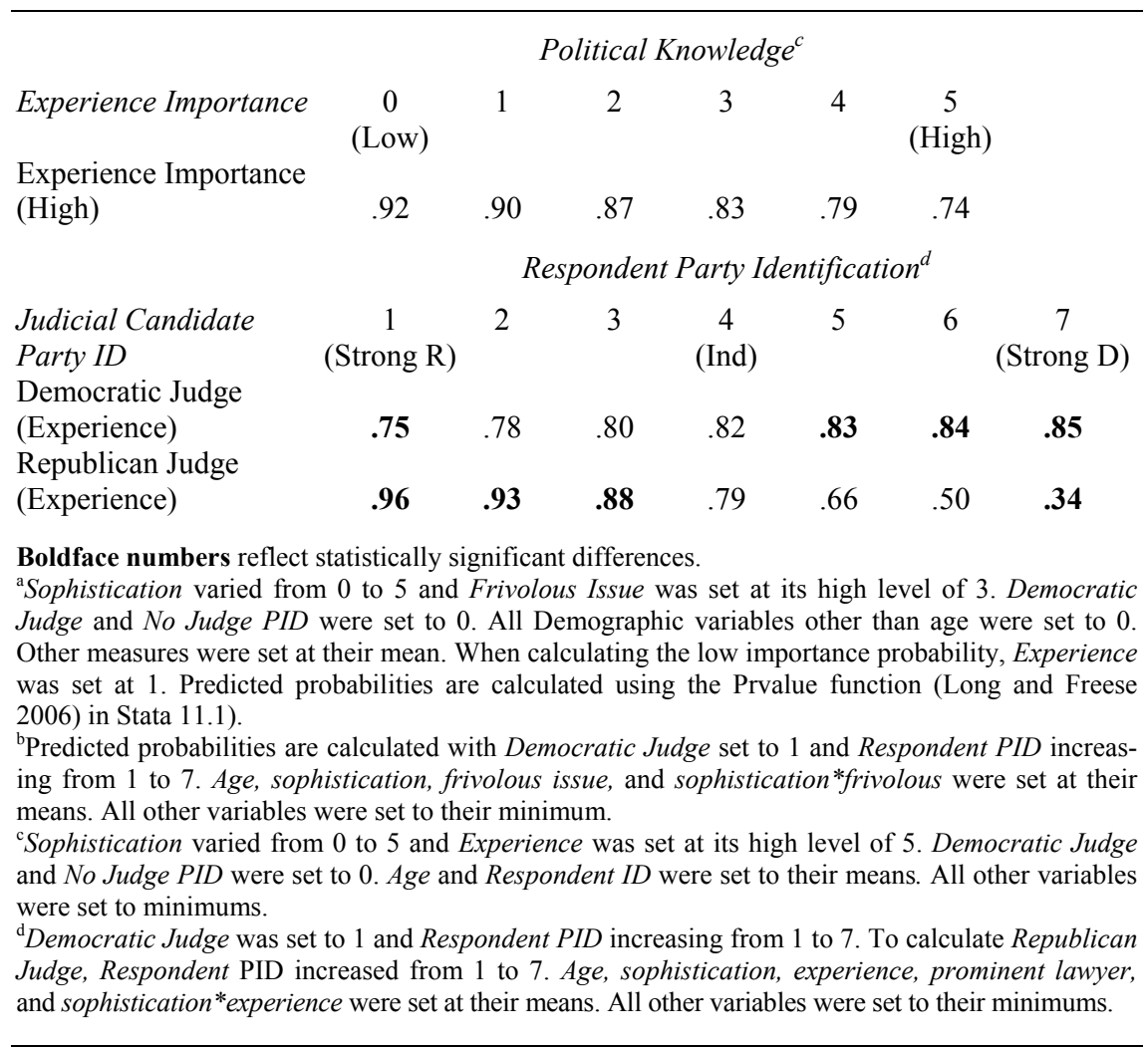


and the Republican judge in the control group. That is consistent as partisanship of the respondent moves from Strong Republican to Strong Democrat (NoJudgePID*RespPID). The coefficient attached to Respondent PID is negative and statistically significant, indicating that as respondents move from Strong Republican to Strong Democrat, they are less likely to support the judicial candidate if the judicial candidate is a Republican (when Democratic Judge and No Judge PID are both set to 0$){ }^{11}$

We find strikingly different results when the judicial candidate is identified as a Democrat (Table 4, Panel 1). Dem Judge*RespPID is positive and statistically significant, demonstrating that as the partisan identification of respondents moves from Strong Republican to Strong Democrat, the probability of supporting a judicial candidate increases and the difference relative to a Republican judge is statistically significant. Figure 1B shows that the effect of the issue on probability of voting for this candidate, relative to voting for a candidate identified as a Republican, is strongest among those respondents who identify themselves as either Republicans or Democrats. Among strong Republicans, the probability of supporting the Democratic candidate is negative relative to the probability of supporting a Republican. However, among those who identify themselves as Independents or Democratic leaners, there is no statistical significance difference in the probability of voting for the Democratic candidate as opposed to the Republican. The effect becomes positive among Democratic and strongly Democratic voters, and once again achieves statistical significance (Figure 1B). We find about a .92 probability that a person identified as a strong Democrat will support the judge identified as a Democrat. That probability drops to .52 among strong Republicans. Likewise, we find only about a .38 probability that a strong Democrat will support a Republican judge. Among strong Republicans, that increases to .94 (Table 5). The results indicate that, similar to other electoral contests, partisanship does play a role in voter decision-making in judicial races - partisans are voting for the judicial candidate of their party. In this analysis, only the partisan identification of the judge varied across manipulations. We find even in the presence of an issue stance, voters in our hypothetical election relied on partisan cues in making decisions.

We also find that one of the variables capturing demographic characteristics achieves a marginal level of statistical significance. Coefficients in Panel 1 demonstrate that African-American respondents are somewhat less likely to vote for the judicial candidate than are Anglo voters, when other factors are held constant. Other variables capturing age, gender, and whether or not the respondent was Latino fail to achieve significance. ${ }^{12}$ This would seem to indicate that demographic characteristics have little influence on probabilities of voting for our hypothetical judicial candidate. 


\section{Model 2: Judicial Experience}

We also estimated how the effect of judicial experience influences support for a candidate. We ask whether that effect of candidate experience is conditioned by political sophistication and how support for experienced partisan candidates varies as our respondents' partisan identifications move from Democrat to Republican (Table 4, Panel 2).

Descriptive tables presented earlier show that experience is critically important to voters in judicial races and that more than nine out of 10 respondents consider experience either important or very important (Table 3 ). Our analyses find that voters are very likely to support an experienced candidate and that political knowledge has little influence on that probability (Table 4, Panel 2). The predicted probability of a voter supporting an experienced candidate is high regardless of the level of political sophistication (Table 5). Few respondents indicated experience was of little importance, so results for that group are, for all practical purposes, meaningless.

As we would expect, Model 2 in Table 4 shows that Respondent PID is negative and significant, demonstrating that Republicans are more likely to support a Republican judicial candidate than are Democratic voters. ${ }^{13}$ As was the case with issues, there is no statistical difference between probabilities of voting for the Republican judge and the judge with no partisan identification, and this is consistent for all levels of Respondent PID. ${ }^{14}$ The analysis finds a significant effect when Democratic Judge and Respondent $P I D$ are interacted. Figure $1 \mathrm{C}$ shows that the probability of supporting a Democratic judge relative to a Republican judge is less when the respondent is a strong or weak Republican identifier than when the respondent is a Democrat. There is no statistically significant difference in the probability of voting for a Democratic or a Republican judge among respondents who lean Republican, are Independents or who lean Democrat. However, the probability of supporting the Democratic candidate as compared to the Republican candidate increases among Democrats and strong Democrats and the result is statistically significant when other factors are held constant (Figure 1C). The strongest effect in this experiment is among Democratic respondents. The probability of a strong Republican supporting an experienced Republican judge is almost .21 higher than a strong Republican supporting an experienced Democratic candidate for judge. The probability of a strong Democrat supporting an experienced Democratic judge is .51 higher than the probability of a strong Democrat supporting an experienced Republican. For Independents, the difference is about .03 , which is statistically and substantively insignificant (Table 5).

In summary, as was the case with the judicial candidate who took a stance on the issue of frivolous lawsuits, the partisan identification of judges 
matters. Democrats are more likely to support Democratic candidates than they are Republican candidates, and Republicans are more likely to support Republicans than they are Democrats. Voters responding to polls may say that partisanship should not matter when voting for judge; yet had partisanship not mattered, we would not have found the differences between candidates identified as either Democrat or Republican.

Similar to Model 1, only one demographic variable was marginally significant. The age variable is negative, meaning that as citizens' age, they are less inclined to support the experienced candidate. Variance in gender, ethnicity, and race appear to have little effect on the probability of supporting judicial candidates in the experience treatment groups.

\section{Discussion}

A central question in our paper addressed whether partisanship outweighs other considerations that might be important in judicial elections like campaign promises or legal experience. The results of this experiment indicate that it does, which is notable because we use individual level data to address a research question often approached from an aggregate perspective. Some individuals rely heavily on party as a shortcut when evaluating judicial candidates. Although partisan cues fundamentally shaped voter choices in this experiment, promising to stop frivolous lawsuits was relevant to the most politically sophisticated subjects. Also, appeals to voters based on legal experience were different than we anticipated.

This experiment contributes to our understanding of how voters react to new-style judicial campaigns by testing whether partisan considerations override issue salience or legal experience. It builds on the research indicating that voters, at least in terms of partisanship, behave in judicial elections as one would expect in other elections. Similar to Rock and Baum (2010), we find that political sophistication conditions how individuals respond to judicial campaigns, particularly as it pertains to issue-based campaigning. By using an experimental design to directly test effect of partisanship on vote choice compared to an issue position or legal experience, our study provides new information about what voters think is important when evaluating judicial candidates. Compared to stopping frivolous lawsuits or legal experience, partisanship dominated subject evaluations of judicial candidates.

Although we expected that legal qualifications would consistently increase the probability of voters supporting the candidate with legal experience, the results of the experiment are more nuanced and somewhat surprising. Partisanship appears to be an overriding influence in voter decisionmaking. Democrats were more likely to support a Democratic judge and 
Republicans more likely to support a Republican. This finding is not inconsistent with literature on other elections. When voters operate in a lowinformation environment, political party identification becomes a powerful cue (Lodge and Hammill 1986; Rahn 1993). In this instance, it appears that voters do default to party identification in forming opinions.

On why experience had little discernable influence, it is possible subjects simply may have interpreted the experience prompts differently than we intended, which could have contributed to the results for legal experience. While James Smith was presented as a lawyer with ten years of experience as a trial judge, and previous findings have found these characteristics sufficient to influence judicial candidates' aggregate vote totals positively (Bonneau and Hall 2009), our hypothetical candidate was not presented as an incumbent running for the Texas Supreme Court. Consequently, subjects were not exposed to a candidate with what might be perceived as the highest level of experience and the electoral benefits accompanying incumbency. In addition, some individuals may have concluded that James Smith was not as experienced as an imagined incumbent. Our design, however, may be a reasonable approximation of an open seat race, which can become a high profile race, particularly when the partisan balance of power on a court is at stake in the election. Future research involving candidates with a range of experience is necessary on this issue to parse the effect of legal experience and partisanship on voting for judicial candidates. It would also be interesting to determine whether campaigning for or against particular decisions made by an incumbent judge matters to voters.

It is also worth noting several other limitations of our experiment. Our findings are not necessarily generalizable to all voters in states with judicial elections, but rather are more appropriately viewed in the context of states with partisan election systems, such as Louisiana or Alabama. Moreover, telephone surveys may not adequately represent campaign discourse and the vignettes involving frivolous lawsuits involved mundane claims lacking the aggressiveness of the most striking (but at this point relatively rare) newstyle judicial campaigns. Yet, while the nature of our vignettes may have contributed to the findings for legal experience, it may strengthen our findings for frivolous lawsuits. Demonstrating that this issue matters to the most sophisticated voters even when it is watered-down indicates that the issue has traction among a portion of the electorate. Even though many judicial elections tend to be relatively issue-free affairs (Abbe and Herrnson 2002), campaign promises such as the one we included to stop frivolous lawsuits appear to influence the most politically sophisticated voters who are also the individuals most likely to get new information. The asymmetrical response to the frivolous lawsuits prompts suggests that higher and lower sophisticates are evaluating and using new information in judicial elections differ- 
ently. More aggressive issue positions might matter to low sophisticates, but it might be unlikely that these individuals will possess the requisite knowledge to make sense of complex legal issues without a shortcut like party identification or cues from political elites (e.g., Zaller 1992; Rock and Baum 2010). In this study, we limited explicit campaign promises to one issue, stopping frivolous lawsuits. Future studies can investigate whether voters respond differently to legal issues with a range of complexity, perhaps by including issues that may be more accessible to a large portion of the public like abortion or same-sex marriage.

There is something to take away from both proponents and opponents of partisan judicial elections; and both those who are and who are not concerned with the new style of judicial elections. We demonstrate that voters in partisan judicial elections, at least in Texas, do not behave uniquely compared to voters in other elections. Proponents of partisan judicial elections may be correct in claiming that voters can make reasonable decisions with little information about candidates if given the powerful shortcut of a candidate's party. In addition, issue positions are relevant to at least a portion of the electorate. Opponents of this style of selecting judges may be troubled that voters are not evaluating judges differently given their asserted special place within our democratic system, but these kinds of normative claims are beyond the present purpose of this project.

\section{NOTES}

${ }^{1}$ Schotland (2010) discusses the impact of issues in the Iowa 2010 retention elections and strings together a number of interesting anecdotal stories on different judicial campaigns, but he simply assumes that issues mattered in those campaigns without presenting any systematic evidence. There is an endless supply of stories in the media about issue effects in judicial elections. Journalists (and some law professors) assume widespread effects of issues on voters in judicial campaigns (see Hasen and Lithwick 2010; Ifill 2010; Sulzberger 2010). This is not unlike what the media do in other types of elections as pointed out by Kaufman et al. (2008); but in the area of judicial politics, few political scientists have systematically explored the extent of the effects of specific judicial campaign issues on voting.

${ }^{2}$ Republican Party of Minnesota v. White (2002). Though there's not much evidence to suggest that the White case has actually caused candidates to become more politicized, in theory the case provides candidates with more legal protection to announce positions on substantive policy issues.

${ }^{3}$ In Ohio, judicial candidates are chosen in partisan primaries, but their partisan affiliation does not appear on the general election ballot. Thus, many judicial scholars refer to this state as semi-partisan.

${ }^{4}$ The response rate was $17.3 \%$ and cooperation rate was $33.7 \%$.The survey lab calculated these rates using the American Association of Public Opinion Research (AAPOR) response rate \#1 and cooperation rate \#1. 


\section{8 | Mark J. McKenzie, Cynthia R. Rugeley, and Michael A. Unger}

${ }^{5}$ In order to determine whether subjects assigned to each group varied on key political attributes and demographic characteristics, we ran difference of means tests for between group comparisons on these variables (e.g., mean of age among subjects assigned to Group 1 compared to Group 2). The results for between group differences were insignificant for political sophistication, race, education and age at the $\mathrm{p}<.05$ level. While random assignment was reasonable, there were some small, yet statistically significant differences. Based on the standard seven point partisanship scale, Group 1 is slightly less Democratic than Group 3 (-0.62). Also, Group 1 had fewer females (.29) compared to Group 4 (.42).

${ }^{6}$ There is no clear answer to what constitutes a well-informed or knowledgeable voter. Scales do provide evidence of some being more knowledgeable than others. Also, researchers acknowledge that political knowledge or sophistication may not be lumped into a single discrete category of knowledge or no knowledge. For a thorough discussion, see Mondak (2001).

${ }^{7}$ In our sample, about eight percent of respondents did not identify as either Republican, Democrat or Independent, but instead identified with some other party. Of course, given our measure of partisanship, the dilemma confronted by us is to either exclude these respondents entirely or treat them as pure independents in the middle of the scale. Some of these respondents probably identify with third parties, and excluding these respondents seems inappropriate. Since these third-party identifiers lean neither Democrat or nor Republican, we believe that for our purposes, treating these respondents as pure independents in the middle of our scale is the appropriate method for dealing with them.

${ }^{8}$ For ease of explanation, we re-polarized the variable measuring support for frivolous by multiplying it by -1 . Doing so re-scaled the variable in the same direction as our dependent variable.

${ }^{9}$ Because of the interaction, the result only applies when political sophistication is set to 0 , the lowest level in our scale.

${ }^{10}$ When the measure of political sophistication is about 3 , the effect on the probability of supporting the candidate is statistically significant. The probability continues to increase to the bounds of the data, a measure of 5 . About $70 \%$ of respondents scored 3 or better on the sophistication scale. We estimated effects at 90 percent confidence intervals. Figures were created using Stata 11.1 for Macintosh and using computer code made available by Brambor et al., at http://homepages.nyu.edu/ mrg217/interaction.html, The solid line is the effect of issue importance on probability of supporting the judicial candidate as political sophistication increases. The dashed lines are 90 percent confidence intervals. The difference in the effect of high issue salience on probability of voting is statistically significant when the confidence intervals are on the same side of 0 .

${ }^{11}$ Using the Brambor et al (2006) computer code, we tested the influence as Respondent PID varied and found no statistical significance at any level.

${ }^{12}$ This conclusion applies to a hypothetical candidate with no race identification.

${ }^{13}$ Because of the interaction, results of Respondent PID pertain to instances in which other variables are set to 0 , or when the judicial candidate is a Republican.

${ }^{14}$ The coefficient for Democratic Judge in Model 2 presented in Table 5 shows a negative and significant coefficient. Once again, this has little substantive meaning as it applies only when Respondent PID is at 0 . 


\section{REFERENCES}

Abbe, Owen G., and Paul S. Herrnson. 2002. How Judicial Election Campaigns Have Changed. Judicature 85(6):286-295.

Arbour, Brian K., and Mark J. McKenzie. 2010. Has the 'New Style' of Judicial Campaigning Reached Lower Court Elections? Judicature 93(4):150-160.

Althaus, Scott L., 1998. Information Effects in Collective Preferences. American Political Science Review 92(3):545-558.

Ansolabehere, Stephen, Shigeo Hirano, James. M. Snyder Jr., and Michiko Ueda. 2006. Party and Incumbency Cues in Voting: Are They Substitutes? Quarterly Journal of Political Science 1(2):119-137.

Aspin, Larry T. 1998. Campaigns in Judicial Retention Elections: Do They Make a Difference? Justice System Journal 20(1):1-15.

Aspin, Larry T. 1999. Trends in Judicial Retention Elections, 1964-1998. Judicature 83(2):79.

Bartels, Larry M. 1996. Uninformed Votes: Information Effects in Presidential Elections. American Journal of Political Science 40:194-230.

Baum, Lawrence. 1987a. Explaining the Vote in Judicial Elections: The 1984 Ohio Supreme Court Elections. Western Political Quarterly 40(2):361-371.

Baum, Lawrence. 1987b. Information and Party Voting in 'Semipartisan' Judicial Elections. Political Behavior 9(1):62-74.

Baum, Lawrence, and David Klein. 2007. Voter Responses to High-Visibility Judicial Campaigns. In Running for Judge: The Rising Political, Financial, and Legal Stakes of Judicial Elections, ed. Matthew J. Streb. New York: New York University Press.

Blais, Andre, and Mathieu Turgeon. 2004. How Good are Voters at Sorting Out the Weakest Candidate in Their Constituency? Electoral Studies 23(3):455-461.

Bonneau, Chris W. 2007. The Dynamics of Campaign Spending in State Supreme Court Elections. In Running for Judge: The Rising Political, Financial, and Legal Stakes of Judicial Elections, ed. Matthew J. Streb. New York: New York University Press.

Bonneau, Chris W., and Melinda Gann Hall. 2009. In Defense of Judicial Elections. New York: Routledge.

Brace, Paul, and Melinda Gann Hall. 1995. Studying Courts Comparatively: The View from the American States. Political Research Quarterly 48(1):5-29.

Brambor, Thomas, William R. Clark, and Matt Golder. 2006. Understanding Interaction Models: Improving Empirical Analyses. Political Analysis 14(1):63-82.

Campbell, Angus, Philip E. Converse, Warren E. Miller, and Donald E. Stokes. 1960. The American Voter. New York: Wiley.

Canes-Wrone, Brandice, and Tom S. Clark. 2009. Judicial Independence and Nonpartisan Elections. Wisconsin Law Review 1:21-65.

Carmines, Edward G., and James A Stimson. 1980. The Two Faces of Issue Voting. American Political Science Review 74(1):78-91.

Champagne, Anthony, and Greg Thielemann. 1991. Awareness of Trial Court Judges. Judicature 74(5)271-276.

Cheek, Kyle, and Anthony Champagne. 2005. Judicial Politics in Texas: Partisanship, Politics and Money in State Courts. New York: Peter Lange Publishing, Inc.

Conover, Pamela Johnston, and Stanley Feldman. 1989. Candidate Perception in an Ambiguous World: Campaigns, Cues, and Inference Processes. American Journal of Political Science 33(4):912-940 
Cobb, Michael D., and James H. Kuklinski. 1997. Changing Minds: Political Arguments and Political Persuasion. American Journal of Political Science 41(1):88-121.

Delli Carpini, Michael X., and Scott Keeter. 1996. What Americans Know about Politics and Why It Matters. New Haven, CT: Yale University Press.

Dubois, Philip L. 1979. The Significance of Voting Cues in State Supreme Court Elections. Law \& Society Review 13(3):757-779.

Dubois, Philip L. 1980. From Ballot to Bench: Judicial Elections and the Quest for Accountability. Austin: University of Texas Press.

Dubois, Philip L. 1984. Voting Cues in Nonpartisan Trial Court Elections: A Multivariate Assessment. Law and Society Review 1(3):395-436.

Druckman, James. 2004. Priming the Vote: Campaign Effects in a U.S. Senate Election. Political Psychology 25:577-594.

Gibson, James L. 2008. Challenges to the Impartiality of State Supreme Courts: Legitimacy Theory and 'New-Style' Judicial Campaigns. American Political Science Review 102(1):59-75.

Griffin, Kenyon N., and Michael J. Horan. 1983. Patterns of Voting Behavior in Judicial Retention Elections for Supreme Court Justices in Wyoming. Judicature 67(2):68-77.

Hall, Melinda Gann. 2001. State Supreme Courts in American Democracy: Probing the Myths of Judicial Reform. American Political Science Review 95(2):315-330.

Hall, Melinda Gann, and Chris W. Bonneau. 2006. Does Quality Matter? Challengers in State Supreme Court Elections. American Journal of Political Science 50(1):20-33.

Hall, Melinda Gann, and Paul Brace. 1989. Order in the Courts: A Neo-Institutional Approach to Judicial Consensus. The Western Political Quarterly 42(3):391-407.

Lodge, Milton, and Ruth Hamill. 1986. A Partisan Schema for Political Information Processing. American Political Science Review 80(2):505-519.

Hasen, Richard L., and Dahlia Lithwick. 2010. Evil Men in Black Robes. Slate. October 26. http://www.slate.com/id/2272086/ (accessed September 14, 2011).

Hojnacki, Marie, and Lawrence Baum. 1992. 'New Style' Judicial Campaigns and the Voters: Economic Issues and Union Members in Ohio. Western Political Quarterly 45(4):921-948.

Ifill, Sherrilyn. 2010. Big Money Set to Flood into Judicial Elections. Salon. March 18. http://www.salon.com/news/opinion/feature/2010/03/18/electing judges open2010 index.html (accessed on September 14, 2011).

Johnson, Charles A., Roger C. Schaefer, and R. Neal McKnight. 1978. The Salience of Judicial Candidates and Elections. Social Science Quarterly 59(2):371-378.

Kaufmann, Karen M., John R. Petrocik, and Daron R. Shaw. 2008. Unconventional Wisdom: Facts and Myths about American Voters. New York: Oxford University Press.

Kiel, L. Douglas, Carole Funk, and Anthony Champagne. 1994. Two-party Competition and Trial Court Elections in Texas. Judicature 77(6):290-293.

Klein, David, and Lawrence Baum. 2001. Ballot Information and Voting Decisions in Judicial Elections. Political Research Quarterly 54(4):709-728.

Long, J. Scott, and Jeremy Freese. 2006. Regression Models for Categorical Dependent Variables Using Stata, 2nd ed. College Station, TX: Stata Press.

Lovrich, Nicholas P., John C. Pierce, and Charles H. Sheldon. 1989. Citizen Knowledge and Voting in Judicial Elections. Judicature 73(1):28-33.

McDermott, Monika L. 1997. Voting Cues in Low-Information Elections: Candidate Gender as a Social Information Variable in Contemporary United States Elections. American Journal of Political Science 41(1):270-283. 
McDermott, Monika L. 1998. Race and Gender Cues in Low-Information Elections. Political Research Quarterly 51(4):895-918.

McDermott, Monika L. 2005. Candidate Occupations and Voter Information Shortcuts. Journal of Politics 67(1):201-219.

McKenzie, Mark J. 2009. Attitudes Toward Electoral College Reform: Understanding Opinion Formation on Complicated Public Policy Issues. Politics \& Policy 37(2): 265-288.

McKenzie, Mark J., and Michael A. Unger. 2011. 'New Style' Campaigning, Citizen Knowledge, and Sources of Legitimacy for State Courts: A Case Study in Texas. Politics \& Policy 39(5):813-814.

McKnight, R. Neal, Roger Schaefer, and Charles A. Johnson. 1978. Choosing Judges: Do the Voters Know What They Are Doing? Judicature 62(2):94-99.

Mondak, Jeffrey J. 2001. Developing Valid Knowledge Scales. American Journal of Political Science 45(1):224-238.

Nelson, Thomas E., and Donald Kinder 1996. Issue Frames and Group-Centrism in American Public Opinion. Journal of Politics 58(4):1055-1078.

Rahn, Wendy M. 1993. The Role of Partisan Stereotypes in Information Processing about Political Candidates. American Journal of Political Science 37(2):472-496.

Ramsey, Ross, and Morgan Smith. 2010. Insurgents Beat Veterans in Several Texas Runoffs. The Texas Tribune April 14. http://www.texastribune.org/texas-politics/2010legislativerunoffs/insurgents-beat-veterans-in-several-texas-runoffs/ (accessed online Nov. 20, 2011).

Reid, Trashel V. 1999. The Politicization of Retention Elections: Lessons from the Defeat of Justices Lamphier and White. Judicature 83(2):68, 70-71.

Rock, Emily, and Lawrence Baum. 2010. The Impact of High-Visibility Contests for U.S. State Court Judgeships: Partisan Voting in Nonpartisan Elections. State Politics and Policy Quarterly 10(4):368-396.

Schotland, Roy A. 2010. Iowa's 2010 Judicial Election: Appropriate Accountability or Rampant Passion? Court Review 46:118-128.

Schultz, (2006). Politicizing Courts Threatens Independence. Saint Paul Pioneer Press, March 23, p. B11.

Squire, Peverill, and Eric R.A.N. Smith. 1988. The Effect of Partisan Information on Voters in Nonpartisan Elections. Journal of Politics 50(1):169-179.

Sulzberger, A.G. 2010. Voters Moving to Oust Judges Over Decisions. The New York Times, September 24. http://www.nytimes.com/2010/09/25/us/politics/25judges.html?_r=1\&hp (accessed September 14, 2011)

Wold, John T., and John H. Culver. 1987. The Defeat of the California Justices: The Campaign, the Electorate, and the Issue of Judicial Accountability. Judicature 70(6):348-355.

Zaller, John, 1992. The Nature and Origin of Mass Opinion. New York: Cambridge University Press. 